\title{
EARTH AND PLANETARY SCIENCES
}

\section{Introduction}

One of the consequences of rapid development the human economic activity is the widespread distribution of anthropogenic landscapes and the significant modification of natural landscapes, which is becoming threatening in some places. In practice, this is reflected as excess of permissible indicators economical (especially agricultural) development of the territory, the imbalance of land structure and their deteriorated ecological status. Particularly in Ukraine the leading place (over $70 \%)$ in land fund's structure belongs to the agricultural lands, about $57 \%$ of the territory is affected by erosion process, about $12 \%$ - by under flooding [1].

At the same time, it is generally acknowledged that sustainable land use can improve the formation and maintain of balanced territorial development. The importance and conceptual principles of organization the sustainable land use were laid out in the 1990s. [2, 3], deepened and expanded at the beginning of the 21st century [4-6], and over the last decade the focus of research has shifted towards developing practical recommendations for optimizing land use at regional and national levels [7-9].

However, in scientific publications comparatively less attention is paid to the consideration of land-use planning as an indispensable primary component of formation balanced development of the territory. The importance of land-use planning is due to the fact that land planning involves the justification of a rational structure of functional land-use, namely: the optimum ratio of agricultural land, forest land, lands of protective and environmental purpose and so on.

The aim of this article is to highlight the importance of land-use planning for balanced territorial development within united territorial communities, mainly by analyzing existing land use and justification recommendations for optimizing land use on a balanced development basis.

\section{Methods}

The particularities of using land planning for the organizing a balanced territorial development are mainly determined by the current legislation certain country regarding the nature, concept and specifics of the organization of this type of work. Ac-

\section{THE ROLE OF LAND-USE PLANNING FOR ORGANIZE THE BALANCED TERRITORIAL DEVELOPMENT WITHIN THE UNITED TERRITORIAL COMMUNITIES}

\author{
Natalia Bubyr
}

PhD, Associate Professor

Department of Physical Geography and Cartography

V. N. Karazin Kharkiv National University

4 Svobody sq., Kharkiv, Ukraine, 61022

bubyr-n@ukr.net

Abstract: It is a well-known fact that sustainable land use can contribute the formation and maintenance of balanced territorial development. At the same time in scientific publications too little attention is paid to the consideration of landuse planning as an indispensable elementary component of sustainable land use.

The aim of this article is to highlight is the importance of in united territorial communities, mainly by analyzing existng land use and justification recommendations for optimizing land use on a balanced development basis.

Land-use planning involves the creation of documentation, ncluding planning and mapping materials, which regulates of land use process within certain administrative unit. In Ukraine, such materials are first of all, a scheme (plan) of land-use certain territorial community, which is compiled on a scale of 1:10000 and contains the current state of land use within the territory of the village council (united territorial community), environmental measures and information on land-use planning for the appropriate perspective. So, the main direction of implementation the ideas of balanced territorial development for the certain administrative unit is the creating a plan for its land-use planning based on the principles of optimization landscape systems on the balanced degarkiv United Territorial Community and justify rec-

On a whole, land-use planning is essential for the organizabalanced (sustainable) development of the territory ince the documental status of all created materials indicates hat they are mandatory for all landowners and land users. disadvantage is the complete dependence of landuse planning on the legislative framework certain country, which complicates the offering of uniform methods of its apKeywords: land-use planning, sustainable land use, balanced territorial development, anthropogenic influence. cording to the current Ukrainian legislation, land planning includes a list of work connected to the developing of land-use documentation, which is presented text and graphic materials in the manner prescribed by law. This materials regulate the use and protection of state, communal and private land, as well as materials of survey and exploration of land on the implementation of projects, etc. (Ukrainian Act "On Land Management"). In the context of the united territorial community, such materials are, first of all, such materials are, first of all, a scheme (plan) of land use certain territorial community, which is compiled on a scale of 1:10000 with drawing the necessary information in accordance with the scale. Content of this plan consists the current state of land use within the territory of the village council (united territorial community), environmental measures and information on land-use planning for the appropriate perspective.

Consequently, the main direction of implementation the ideas of balanced nature management for the certain united territorial community is the creating a plan for its land planning based on the principles of optimization landscape systems on the balanced development basis. In the case of already mature land use within the community, which includes majority of current administrative units, it is necessary to:

1) determine the degree of rationality the existing land planning;

2) offer directions of optimization land planning for this territorial community;

3) update the land-use planning documentation taking into account the identified directions of land use optimization.

\section{Results}

The experimental part of the work was carried out on the materials of the Nedogarkiv United Territorial Community of Poltava region, Ukraine.

The Nedogarkiv United Rural Territorial Community was formed on August 13, 2015 by merging the territories of Nedogarkiv and Maxymivsky village councils. The area of community is $84.77 \mathrm{~km}^{2}$, the population, as of $2018,-3,551$ people.

In the land fund's structure of Nedogarkiv Territorial Community a leading place belongs to the agricultural land, espe- 
cially arable land, which cover $67 \%$ of the territory; in second place are forests and wooded areas, whose share is $9.62 \%$ of the community's territory; on the third - pastures and settlements; the land of water fund occupy an insignificant proportion only $5.27 \%$, and industrial land - only $1.48 \%$ (Fig. 1).

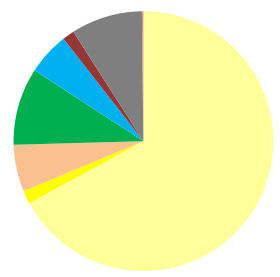

$1 \backsim 2 \backsim 3 \backsim 4 \backsim 5 \backsim 6 \backsim 7 \backsim 8$

Fig. 1. The land fund's structure of Nedogarkiv Territorial Community: 1 - arable land, 2 - hayfields, 3 - pastures,

4 - forests and wooded areas, 5 - land of water fund,

6 - industrial land, 7 - settlements, 8 - others land

There is a significant uneven distribution of forest and water fund lands within the Nedogarkiv territorial community: on the territory of former Nedogarkiv village council, area of the forest lands a threefold increase and area of the water fund lands a eightfold increase than the territory of former Maxymivsky village council (Fig. 2) due to the conservation of natural landscapes such as forests, meadows and floodplains in the southeastern part of the former Nedogarkiv village council.

In general, the forest and wooded lands of the Nedogarkiv rural territorial community are not of industrial importance. Although the territory of community belongs to the forest-steppe zone, the area of forest plantations, as noted above, is very insignificant.

The lands of the Nedogarkiv rural united territorial community are significantly affected by anthropogenic influence. First of all, due to the considerable ploughing of the territory, in fact, there are no areas of the natural steppe because of the share of arable land in some places reaches $85 \%$ (the territory of the former Maxymivsky village council).

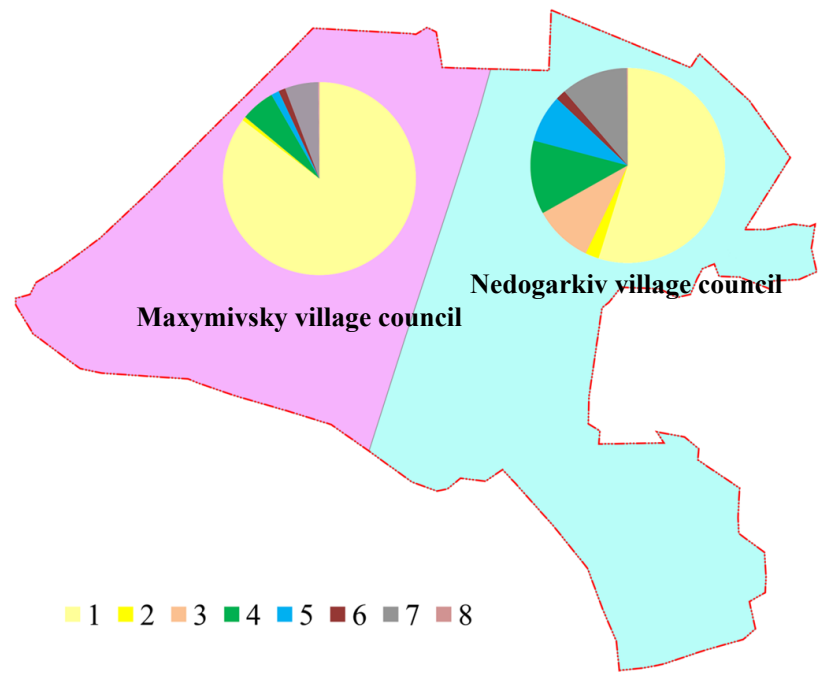

Fig. 2. Structure of the land fund within the former territories Maximivsky and Nedogarkiv village councils:

1 - arable land, 2 - hayfields, 3 - pastures, 4 - forests and wooded areas, 5 - land of water fund, 6 - industrial land, 7 - settlements, 8 - others land
To find out the degree of influence the composition of current land structure on the ecological stability of the study area, which in turn depends on the anthropogenic influence including plowing and intensity of land using, construction of the territory, etc., the coefficient of ecological stability of land use in the territory of Nedogarkiv union community is calculated based on the formula 1 [10]:

$$
K_{\text {ec.st. }}=\frac{\sum K_{l i} \times P_{i}}{\sum P_{i}} \times K_{p},
$$

where $K_{l i}$ - coefficient of ecological stability of the $i$-th sort; $P_{i}$ - area of the land of the $i$-th sort; $K_{\mathrm{p}}$ - coefficient of morphological stability of the relief $\left(K_{\mathrm{p}}=1,0-\right.$ for stable territories and $K_{\mathrm{p}}=0.7-$ for unstable areas).

The calculated value (0.28) indicates that the study area is ecologically unstable because it is less than 0.33 [10]. Accordingly, the issue of optimizing the structure of land within the Nedogarkiv United Territorial Community is urgent.

To determine the degree of anthropogenic load on the land of Nedogarkiv union community, the corresponding coefficient was calculated by the formula (2) [10]:

$$
K_{a . l .}=\frac{\sum A \times S}{\sum A},
$$

where $A$ - area of land with appropriate level of anthropogenic load; $S$ - score of the corresponding land with a certain level of anthropogenic load, which is determined on a scale from one to five.

The calculated result of the anthropogenic load factor (3.73) does not significantly exceed the average for Ukraine (3.4), which indicates that the study area is on the border between average and significant anthropogenic load.

On the whole, based on analysis of the processed material we can identify the main problems of the current state of land use within Nedogarkiv United Territorial Community. Firstly, it is a high level of agricultural development of the territory. Secondly, today there is a tendency to increase the amount of agricultural land (by $10 \%$ in 2015-2018) combined with a decrease in the area of perennial crops. More other, the consequence of irrational land use is a certain nutrient imbalance in the soil cover, which is caused by insufficient application of mineral and organic fertilizers and fertilizer application when harvesting from the arable layer. This is reflected in the general deterioration of the soil's quality characteristics due to their degradation and depletion, decrease in the humus content of the soil cover, and decreases its productivity.

As a result of research, areas are identified that need priority attention to the normalization of current land use. These areas include:

a) places of spreading the erosion processes both near existing watercourses and in the southern part of the territory of the community bordering on the Kremenchuk reservoir;

b) places where were found the flooding process of the territory, namely wetlands, located south of Nedogarkiv village;

c) places where agricultural land is overgrown, for example areas located between the villages of Paschenko and Rokytne-Donivka.

Taking everything into consideration, there is all reason to argue that in order to achieve balanced land use within the community it is necessary to:

a) to change the functional purpose of land by reducing the part of arable land and increasing pastures, first of all within the territory of the former Maksymivsky Village Council; 


\section{EARTH AND PLANETARY SCIENCES}

b) add the list of conservation measures to improve the land conditions, in particular concerning the restoration and conservation of lands, the reclamation of disturbed lands, the protection of lands from erosion, flooding, water logging;

c) update the existing land-use planning documentation with taking into account all the above mentioned statements.

\section{Discussion and conclusions}

On a whole, land-use planning is essential for the organization of balanced (sustainable) development of the territory, owing to the fact, that this planning includes creating planning and mapping materials, which contains the current state of land use within the territory of the village council (united territorial community), environmental measures and information on land-use planning for the appropriate perspective. The documental status of all created materials indicates that they are mandatory for all landowners and land users. Therefore, in case of keeping on the concept of balanced territorial development during the process of creating planning and mapping land use materials, it is possible to significantly increase the practical implementation statements of this concept in the reality.

At the same time, it should be noted that the complete dependence of land planning works on the legislative framework certain country essentially complicates the offering of uniform methods that would be suitable for several states or individual regions of the world.

\section{References}

1. Pohurelskyi, S. P. Martyn, A. H. (2011). Formuvannia optymalnykh spivvidnoshen zemelnykh uhid yak osnova staloho pryrodokorystuvannia. Zbirnyk naukovykh statei «III-ho Vseukrainskoho zizdu ekolohiv z mizhnarodnoiu uchastiu». Vol. 2. Vinnytsia, 503-505. Available at: http://eco.com.ua/arh_konf_3vze

2. Dumanski, J. (1994). International Workshop on Sustainable Land Management for the 21st Century: Summary. Workshop Proceedings. Agricultural Institute of Canada, Ottawa, 50.

3. Smyth, A. J., Dumanski, J. (1993). FESLM: An international framework for evaluating sustainable land management. A discussion paper. World Soil Resources Report 73. Food \& Agriculture Organization, Rome, 74.

4. Kavaliauskas, P. (2006). Landscape planning governance system: Towards sustainable and balanced regional policy. 4th International Conference: Citizens and Governance for Sustainable Development. Vilnius, 6-11.

5. Opdam, P., Foppen, R., Vos, C. (2001). Bridging the gap between ecology and spatial planning in landscape ecology. Landscape Ecology, 16 (8), 767-779. doi: https://doi.org/10.1023/a:1014475908949

6. Heistermann, M., Müller, C., Ronneberger, K. (2006). Land in sight? Achievements, deficits and potentials of continental to global scale land-use modeling. Agriculture, Ecosystems \& Environment, 114 (2-4), 141-158. doi: https://doi.org/10.1016/ j.agee.2005.11.015

7. Huber, R., Bugmann, H., Buttler, A., Rigling, A. (2013). Sustainable Land-use Practices in European Mountain Regions under Global Change: an Integrated Research Approach. Ecology and Society, 18 (3). doi: https://doi.org/10.5751/es-05375-180337

8. Pérez-Soba, M., Paterson, J., Metzger, M. J., Gramberger, M., Houtkamp, J., Jensen, A. et. al. (2018). Sketching sustainable land use in Europe by 2040: a multi-stakeholder participatory approach to elicit cross-sectoral visions. Regional Environmental Change, 18 (3), 775-787. doi: https://doi.org/10.1007/s10113-018-1297-7

9. Stoiko, N., Parsova, V. (2017). Environmental dimensions of rural development in land use planning circumstances in Ukraine. Engineering for rural development, 964-969. doi: https://doi.org/10.22616/erdev2017.16.n197

10. Tretiak, A. M., Tretiak, R. A., Shkvyr, M. I. (2001). Metodychni rekomendatsiyi otsinky ekolohichnoi stabilnosti ahrolandshaftiv i silskohospodarskoho zemlekorystuvannia. Kyiv: IZ UAAN, 15. 